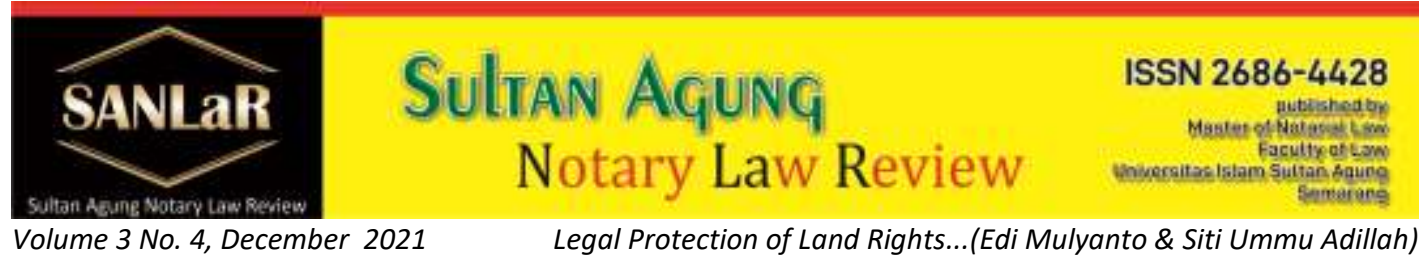

\title{
Legal Protection of Land Rights Certificate Holders in Certificate Blocking Event by Land Office
}

\author{
Edi Mulyanto*) and Siti Ummu Adillah**) \\ ${ }^{*}$ Faculty of Law, Universitas Islam Sultan Agung (UNISSULA) Semarang, E-mail: \\ notariusedi@gmail.com
${ }^{* *}$ Faculty of Law, Universitas Islam Sultan Agung (UNISSULA) Semarang, E-mail: ummu@unissula.ac.id

\begin{abstract}
The certificate is a certificate of proof of rights that applies as a strong means of proof regarding physical data and juridical data, and this evidence is not the only evidence, only strong evidence. This research uses sociological juridical. Sociological juridical research identifies and conceptualizes law as a real and functional social institution in a real life system. This study comes in: 1) Blocking Defects in Article 1 point (1) of the Regulation of the Minister of ATR/Head of BPN Number 13 of 2017 about the procedure for blocking and confiscation is an administrative action of the Head of the Land Office or an appointed official to determine the status quo (freezing) on temporary land rights against changes to land law. 2) The state should protect the holder of the Land Rights Certificate because of the good faith of the holder and the state's decision to issue a certificate as proof of land rights which the state should not cancel without compensation. 3) Blocking that is not in accordance with Permen ATR/Ka.BPN 13 of 2017 about the procedure for blocking and confiscation does not only result in legal certainty not being realized, but also causes losses for the owner of the blocked certificate, both material and immaterial losses. Blocking cases has the potential to cause financial losses to the owner of the blocked certificate. Due to the block, the owner cannot access his land certificate. 4) Obstacles to land rights holders in the registration of the block because the land rights are disputed and confiscated by the Court or a dispute outside the court, the Land Rights are confiscated by PUPN/KPKNL in connection with the settlement of state receivables, so the parties are requested by the Head of the Land Office for blocking. The legal consequences for the owner of the certificate for blocking the Certificate of Land Rights at the Land Office are that the land is temporarily unable to take legal action and also the Land Office has the authority to refuse the registration of the Transfer and Transfer of Names to the Land Rights.
\end{abstract}

Keywords: Legal Protection; Certificate; Block. 


\section{Introduction}

Land for human life has a very important position. This is because almost all aspects of life, especially for the Indonesian people, cannot be separated from the existence of land which can not only be viewed from the economic aspect, but includes all their lives and livelihoods. Land has multiple values, so the terms homeland and bloodshed are used by the Indonesian people to describe the territory of the country by describing an area dominated by land, water, and sovereign land.

Land regulations are contained in Act No. 5 of 1960 concerning Basic Agrarian Regulations, then followed by the making of other laws and regulations as the elaboration and implementation of the Basic Agrarian Law, namely, among others, Government Regulation Number 10 of 1960 which has replaced by Government Regulation Number 24 of 1997 concerning Land Registration and Regulation of the Minister of Agrarian Affairs/Head of the National Land Agency Number 3 of 1997 concerning provisions for the implementation of Government Regulation Number 24 of 1997 concerning Land Registration.

Article 19 of Act No. 5 of 1960 concerning Agrarian Principles (UUPA) explicitly mandates the government to carry out land registration throughout Indonesia, with the aim of achieving legal certainty, land registration is a series of activities carried out by the government continuously, continuously, and regularly includes the collection, processing, bookkeeping and presentation and maintenance of physical data and juridical data, in the form of maps and lists, regarding land parcels and apartment units, including the issuance of certificates as proof of rights for land parcels that are already have rights and ownership rights to the apartment unit as well as certain rights that burden it. ${ }^{1}$

The certificate is a certificate of proof of rights that applies as a strong means of proof regarding physical data and juridical data, in accordance with the data contained in the letter of measurement and the book of land rights in question. ${ }^{2}$ meaning that the law only provides a guarantee for the proof of ownership rights to someone, and this evidence is not the only evidence, only strong evidence. ${ }^{3}$ Certificates of land rights are not the only absolute evidence, on the contrary,

\footnotetext{
${ }^{1}$ Parlindungan, AP, 1988, Pendaftaran Tanah Tanah dan Konfersi hak milik atas tanah menurut UUPA, Alumni, Bandung, p. 2

${ }^{2}$ Lubis. Yamin dan Lubis. Rahim, 2010, Hukum Pendaftaran Tanah, Mandar Maju, Bandung, p. 112

${ }^{3}$ Ibid, p. 112
} 
they are only preliminary evidence which can be withdrawn at any time by other parties who are proven to be more authoritative. ${ }^{4}$

In its implementation, although land registration has been carried out, the occurrence of land disputes in the midst of the community has never subsided, which has even reached the filing of a lawsuit to the Court, which resulted in the blocking of the certificate of land rights by the Land Office. This is because the certificate as a strong means of proof does not guarantee legal certainty for its owner. Moreover, in Article 32 PP No. 24 of 1997 provides an opportunity where as long as there are other parties who feel entitled to sue the party whose name is listed on the certificate in a civil manner to the general court, or sue the Head of the BPN/Head of the Land Office, the State Administrative Court. ${ }^{5}$ The objected party may apply for recording in the land book or better known as land blocking or block registration.

Regarding the application for land blocking, it can be submitted by the objecting party, but the application for registration of the block is not immediately granted by the Banjarnegara Regency Land Office, because in practice land blocking must be carried out with clear reasons, which has been explained in Article 4 paragraph ( 2) Regulation of the Minister of Agrarian Affairs Number 13 of 2017 concerning Procedures for Blocking and Confiscation, that: "In an application for registration of a block, it must include a clear reason and be willing to carry out an examination of the application in question". The parties who apply for the registration of the blocking of the land are indeed the parties who have the right, have a legal relationship to the land and indeed have an interest in the land that is the object of the dispute.

Blocking that has been deleted by itself or has been revoked, then any form of change or transfer of rights can be implemented or cannot be prevented, of course with an official note from the local Land Office that the certificate can be processed because there is no dispute or there is no problem. The problem of recording in the land book against certificates of land rights or Ownership Rights to these Flats has been regulated in the Regulation of the Minister of Agrarian Affairs and Spatial Planning/National Land Agency Number 13 of 2017 concerning Procedures for Blocking and Confiscation, but in fact in the implementation of block registration it is illegal commercial and sociological in causing dilemmas related to the legal consequences of the status of blocked land rights certificates.

${ }^{4}$ Isnaini. Moch, Benda Terdaftar Dalam Konstelasi Hukum Indonesia, Jurnal Hukum, Nomor 13 Volume 7, 7 April 2000, p. 56

${ }^{5}$ Sutedi, A 2010, Peralihan Hak Atas Tanah dan Pendaftarannya, Sinar Grafika, Jakarta, p. 2-3 
Legal problems occur when there is a registration block by the Land Office that is requested and carried out by interested parties which has an impact on being hampered and the threat of cancellation of buying and selling transactions that will be carried out between buyers in good faith and the seller. Block recording in the land book applied for by interested parties for land rights certificates,

At the Banjarnegara Regency Land Office, there is often a block recording of the land book, one of which is information obtained based on the Land Registration Certificate Number: 1188/SKPT/VIII/2018, in the statement there is an explanation that the object of SHM land no. 263/Batur on behalf of Zainal Arifin Samil, MA has been blocked since 16-01-2017, contrary to this there is a provision that the records in the land book are automatically deleted within 30 (thirty) days, but until now the land book records related to the blocking have not been erased and there is no further legal action from the block applicant/interested party on the land object. ${ }^{6}$

The blocking and confiscation of Land Rights at the Banjarnegara Regency Land Office has given legal consequences to these Land Rights, as stipulated in Article 39 of Government Regulation Number 24 of 1997 concerning Land Registration, explaining that PPAT is prohibited from making a deed of transfer of land rights if it is not shown to him. The original certificate of the land rights. Then there is the obligation of PPAT to check the Land Rights Certificate at the Land Office before making the Deed of Transfer of Land Rights.

\section{Research Methods}

This research uses sociological juridical research type. The sociological juridical approach is to identify and conceptualize law as a real and functional social institution in a real life system. The sociological juridical approach emphasizes research that aims to obtain legal knowledge empirically by going directly to the object, namely knowing a qualitative picture of legal protection for Land Rights Certificate holders in the event of a certificate blocking by the Banjarnegara Regency Land Office.

\footnotetext{
${ }^{6}$ The author's explanation, based on the Government Administration Law Number 30 of 2014, it should not take 30 days and a record in the land book even though the blocking has not been removed and there is no further legal action from the block applicant and interested parties to the land object, the blocking automatically it must have been abolished in accordance with the Government Administration Law which guarantees basic rights and provides protection to citizens and guarantees state duties as required by a legal state in accordance with Article 27 paragraph 1, Article $28 \mathrm{~d}$ paragraph 3, Article $28 \mathrm{f}$ and Article 28 I paragraph 2 of the 1945 Constitution of the Republic of Indonesia
} 
Data collection techniques used in this research are field studies and literature studies, namely data collection by reading laws and regulations, official documents and literature that are closely related to the problems discussed based on secondary data and conducting interviews so that verbal interaction occurs directly between the interviewer and the respondent.

\section{Results and Discussion}

\subsection{Land Rights Certificate Blocked by the Banjarnegara Regency Land Office}

The procedure for applying for block registration was previously regulated in the Attachment to Regulation of the Head of the National Land Agency Number 1 of 2010. In Appendix III, however, it is not explained in detail, such as not stipulating an assessment is carried out before the registration of the block is carried out even though this study needs to be carried out so that the land office does not receive an inappropriate block. Block registration in Article 1 point (1) of the Regulation of the Minister of ATR/Head of BPN Number 13 of 2017 is an administrative action of the Head of the Land Office or an appointed official to determine the status quo (freezing) of temporary land rights against acts law on the land. In the case of recording in the land book or blocking of land rights certificates, then the object is a right to land or property rights to an apartment that will be the object of a lawsuit in court. Block registration can be submitted by individuals, legal entities, and law enforcement officers.

The registration of block certificates of ownership of land rights is carried out and carried out by BPN by suspending temporary land rights against legal actions and legal events on the land. Block certificates of ownership of land rights include recording and removing blocks. Broadly speaking, the provisions relating to certificate blocking are contained in several regulations, among others, Article 126 of the Ministerial Regulation of ATR/KBPN No. 3 of 1997 and the Minister of Agrarian Affairs/KBPN No. 13 of $2017 .^{7}$

The request for blocking registration is continued with the review and recording process. The process is carried out within a maximum period of 3 (three) working days since the complete application letter is received. This must be done immediately to avoid any third party applying for the transfer of rights before the block is approved. If it has been recorded in the land book, then all forms of such changes cannot be made because the number of the relevant land rights has been blocked. Article 11 of the Regulation of the Minister of ATR/Head of BPN Number 13 of 2017 explains that if the results of the study receive a registration

${ }^{7}$ Naila Huurin In, "Implementasi Blokir Sertipikat Kepemilikan Hak Atas Tanah Di Kantor Bpn Kota Surabaya", Simposium Hukum Indonesia. Volume 1. Volume 1 Number 1 of 2019, p. 311. 
application, the head of the land office or the appointed official shall carry out the block registration. However, if the results of the assessment reject the application for registration, the head of the land office shall notify in writing through an official letter to the block applicant and/or the parties concerned along with the reasons for the refusal. Block recording can be done manually or electronically. Block registration is carried out by the head of the land office or the appointed official in the relevant land book and measuring document. Block registration shall at least contain information regarding the time (hours, minutes and seconds) and date of recording, the subject submitting the application, and the reason for the application.

The writing of block registration is recorded in the land book, in the registration column for the registration of the transfer of rights, encumbrances and other records; and the letter of measurement, on the sheet of the picture of the letter of measurement that is still available. If there is no empty space on the measuring letter to record the block, the block recording is carried out on separate paper and attached to the measuring letter as stated in Article 12 of the Regulation of the Minister of ATR / Head of BPN Number 13 of 2017 registration and affixed with the stamp of the land office.

After the registration of the block is ratified, the head of the land office or an official who has duties in the field of agrarian legal relations shall notify in writing through an official letter to the block applicant and/or the parties concerned appropriately. Andi Mardiani (2008) in his research entitled "Implementation of Recording in the Land Book according to the provisions of Article 126 paragraph (1) and (2) of the Regulation of the State Minister of Agrarian Affairs / Head of the National Land Agency Number 3 of 1997 (study at the Banjarnegara Regency Land Office)" revealed that the Banjarnegara Regency Land Office blocking certificates does not meet the provisions of Article 126 paragraphs (1) and (2) of the Regulation of the State Minister of Agrarian Affairs/Head of the National Land Agency Number 3 of 1997 is an implementation of the precautionary principle of the Banjarnegara Regency Land Office in the context of realizing a government that is especially in the land sector.

The land office does not immediately accept the incoming block application but must ensure that the applicant for the registration of the block actually has a legal relationship with the land to be blocked. That can be seen from certificates, lawsuits, or deed of sale and purchase. The reasons that cause the application for blocking registration at the Banjarnegara Regency Land Office include:

a. There is a dispute.

b. Distribution of inheritance. 
c. Distributing wealth.

d. There is a police investigation.

e. The buyer's initiative because it has not been renamed.

f. Lost certificate.

Blocking based on the provisions of Article 45 paragraph (1) letter e PP 24 of 1997 is carried out by the Head of the Land Office with the consideration to avoid any criminal risk as regulated in Articles 416 and 417 of the Criminal Code (KUHP) which can be interpreted broadly, namely exceeding authority of office as Head of the Land Office. To be clear, in the case of blocking, if the court judge's decision states that blocking is not his authority, then based on that decision the block is opened or deleted and there is a transfer of certificates which causes losses for the block applicant (plaintiff) who is won in the Court's decision,

Meanwhile, the notion of confiscation comes from the terminology of Beslag (Netherlands) and the Indonesian term "Beslah" but the standard term is confiscation or confiscation. According to M. Yahya Harahap, the purpose of the confiscation of collateral (conservatoir beslag) as regulated in Article 227 HIR is so that the confiscated goods are not embezzled or exiled by the defendant during the trial process, so that when the decision is carried out, the payment of debt demanded by the plaintiff can be fulfilled. by selling the confiscated goods. Thus, the act of confiscation of the defendant's property is not to be handed over and owned by the plaintiff (the applicant for confiscation), but to pay off the payment of the defendant's debt to the plaintiff. ${ }^{8}$

\subsection{Legal Protection for Land Rights Certificate Holders in the Case of Certificate Blocking by the Banjarnegara Regency Land Office}

Satjipto Rahardjo stated that legal protection is an effort to protect a person's interests by allocating a power to him to act in his interests. ${ }^{9}$ Muchsin stated that Protection Law is an activity to protect individuals by harmonizing the relationship of values or rules that are manifested in attitudes and actions in creating order in the association between fellow human beings. ${ }^{10}$

Maintenance of Land Registration data is carried out if there is a change in the physical data or juridical data of the registered Land Registration object. The right holder concerned must register the change in question with the Land

\footnotetext{
${ }^{8}$ Harahap, M., 2007, Hukum Acara Perdata. Jakarta: Sinar Grafika, p. 29.

${ }^{9}$ Rahardjo, Satjipto, 1983, Permasalahan Hukum di Indonesia, Bandung: Alumni, p. 121

${ }^{10}$ Muchsin, 2003, Perlindungan dan Kepastian Hukum Bagi Investor Dilndonesia, Surakarta: Magister Ilmu Hukum Program Pascasarjana Universitas Sebelas Maret, p. 14-20.
} 
Office. The PPAT Deed is one of the data sources for the maintenance of Land Registration data. Therefore, it must be made in such a way that a solid basis can be provided for the registration, transfer and assignment of the rights in question. Therefore, based on the Regulation of the State Minister of Agrarian Affairs/Head of the National Land Agency Number 3 of 1997 concerning Provisions for the Implementation of Government Regulation Number 24 of 1997 concerning Land Registration, PPAT is responsible for examining the requirements for the validity of the legal act concerned, ${ }^{11}$

Certificate as the last product of land registration is a certificate of proof of rights containing a copy of the land book accompanied by a Letter of Measurement containing juridical data and physical data on land parcels, serves as a strong evidence tool, implies that as long as it cannot be proven otherwise, physical data and data juridical data stated in it must be accepted as true data. Individuals or legal entities who feel that their interests have been harmed by the issuance of the Land Rights Certificate have the right to file a lawsuit to the Court. ${ }^{12}$ Therefore, parties who feel that their interests have been harmed can block the Land Rights Certificate by submitting it to the local Land Office.

According to the provisions in Article 37 paragraph (1) of Government Regulation 24 of 1997 in conjunction with Article 94 PMA/KBPN Number 3 of 1997, in addition to being traded, the transfer of rights can also occur due to grants, swaps, sharing of joint rights, due to appointment of auctions, court decisions, Inheritance, will and inclusion in the company. Except because of an auction, the Transfer of Land Rights can only be registered if it is proven by a deed made by the authorized PPAT according to the applicable laws and regulations. One of the reasons PPAT refuses to make a deed is if the object of the legal action (land) in question is in dispute. In Article 39 paragraph (1) letter a Government Regulation Number 24 of 1997 concerning Land Registration it is stated that the PPAT refuses to make a deed if, regarding land parcels that have been registered or Ownership Rights on Flats, the original certificate of the right in question is not submitted to him or the certificate submitted is not in accordance with the lists in the Land Office. PPAT is obliged to check the certificate at the local Land Office.

Legal disputes arise from complaints from a party (person/legal entity) containing objections and claims for land rights both on land status, priority and ownership in the hope of obtaining administrative settlements in accordance with applicable regulations. The event of blocking the certificate is usually seen when the PPAT official will make a Deed of Transfer of Land Rights, a Deed of

\footnotetext{
${ }^{11}$ Harsono, Boedi, op.cit, p. 506-507

${ }^{12}$ Ghazali, Kurniawan, op.cit, p. 68
} 
Assignment of Land Rights or a Deed of Granting of Authorization for Encumbering Mortgage Rights. Before making and signing the deed, PPAT is obliged to carry out inspection or checking of certificates at the land office which aims to find out information on the conformity of physical data and juridical data on the certificate with the land book at the land office. If there is a data discrepancy between the certificate and the data recorded in the land book, the land office will issue a Land Registration Certificate (SKPT) for the PPAT based on the data recorded at the Land Office. If all the data in the certificate is correct, the Land Office will affix a stamp as proof that the certificate data is true.

Knowing that the Land Rights Certificate is in a blocked state, PPAT cannot make a Deed of Transfer of the Land, if PPAT still makes a deed of transfer of the land that is in a blocked state, it can be null and void, as stipulated in Article 39 paragraph (1) letter $f$ of a Government Regulation Number 24 of 1997 concerning Land Registration which stipulates that: "the object of the legal action concerned is in a dispute regarding its physical data and or juridical data".

Regulation of the Minister of State for Agrarian Affairs/Head of the National Land Agency Number 13 of 2017 concerning Procedures for Blocking and Confiscation Article 1 paragraph (1) Recording of blocks is an administrative action of the Head of the Land Office or an official appointed to determine the status quo (freezing) on land rights temporary nature of legal actions and legal events on the land.

The rights of legal subjects to a plot of land by means of evidence in the form of a certificate must be protected considering that the certificate of land rights is written evidence made by an authorized public official, therefore according to Article 164 HIR and Article 1866 of the Civil Code is authentic evidence that has strength perfect proof, in Article 32 (2) Government Regulation No. 24 of 1997 it is clearly stipulated that the certificate is a certificate of proof of rights that applies as a strong means of proof. Based on SEMA No. 589/PAN.2/54/P09/SK.Perda dated December 28, 2009 stated that the block cannot be implemented if the certificate of ownership is still encumbered with mortgage rights, if the blocking is to be carried out then the certificate must be roya first. The SEMA confirms that the blocking process carried out is not legally valid.

With the blocking of land rights, the Land Office gives legal consequences to land rights, both in the transition and the imposition of land rights. With the blocking status of land rights, temporarily the owner of the certificate cannot make the transfer or assignment of land rights because PPAT as an official in making the deed cannot carry out his duties, as stipulated in Article 39 of Government 
Regulation Number 24 of 1997 is prohibited for PPAT to make a deed, if the registered land is not shown the original certificate, or the object is blocked.

\subsection{Handling Cases of Blocking Land Rights Certificates in Banjarnegara Regency}

Blocking that is not in accordance with Permen ATR/Ka.BPN 13 of 2017 does not only result in legal certainty not being realized, but also causes losses for the owner of the blocked certificate, both material and ideal losses. Material losses include real losses suffered and no profit is obtained, while immaterial losses such as fear, illness, loss of pleasure in life. Blocking cases has the potential to cause financial losses to the owner of the blocked certificate. Due to the block, the owner cannot access his land certificate.

Provisions for blocking certificates can be seen in Article 45 paragraph (1) letter e PP No. 24 of 1997 concerning Land Registration which states that the Head of the Land Office refuses to register the transfer or assignment of rights, if the land in question is the object of dispute in the Court. Regarding the refusal to register transfers and land assignments by the Head of the Land Office in relation to the application for block certificates, it is further regulated in Article 126 and Article 127 of the Regulation of the State Minister of Agrarian Affairs/Head of the National Land Agency no. 3 of 1997 concerning Provisions for the Implementation of PP No. 24 of 1997 concerning Land Registration.

In addition to being regulated in PP 24 of 1997, PMNA / Ka.BPN 3 of 1997, the blocking regulation is also regulated in the Regulation of the Minister of Agrarian Affairs and Spatial Planning / Head of the National Land Agency Number 11 of 2016 concerning Settlement of Land Cases and Regulation of the Head of the National Land Agency Number 1 of 2010 concerning Service Standards and Land Regulations. The registration of blocks and confiscations that are still scattered in several regulations, is incomplete, not uniform, and does not match the demands which have the potential to become an obstacle to achieving orderly land administration. The government seeks to resolve these obstacles through the establishment of special regulations regarding blocking and confiscation.

Based on the above provisions, it can be seen that the deletion of records in the land book due to the stipulated period of 30 days from the date of registration of the applicant did not follow up with a lawsuit to the Court or expired. The deletion of records can also be due to being revoked at the request of the applicant before that time expires, i.e. before 30 days from the date of blocking.

Regarding the deletion of records in the land book or blocking of certificates by themselves (expired), then it can also be called notes or block deletes or null and 
void by law, meaning that recording in the land book or blocking of certificates is considered never to have occurred. Consequently, the Head of the Land Office at the request of the interested party or his proxies may not refuse to register the transfer and the assignment of rights if the land concerned is not the object of dispute in the Court. PPAT can also make a deed of transfer or assignment of rights because the land is not in dispute in the Court, of course, after it is stated that the land book is clean of records by the Land Office ${ }^{13}$.

Meanwhile, the deletion of the block record at the request of the applicant himself or his proxy to the Head of the Land Office can be carried out before the 30 day period has elapsed and not proceed to the Court. Requests for deletion of records or blocking must attach evidence in the form of a deed of reconciliation or a statement letter from the parties to the dispute. The consequence is also the same as the automatic deletion of records (expired) or deletion/falling out by law, namely that transfer registration or assignment of rights by the Land Office can still be carried out as well as the making of a deed of transfer or assignment of rights by PPAT.

In the process of removing the block, it must be done by or the person who blocked it. If the blocking is carried out by a certain agency with an official letter, the removal of the block is also carried out with an official letter.

Blocking records by individuals or legal entities can be deleted if the blocking period ends and is not extended by the party requesting the registration has withdrawn the request before the expiration period, the Head of the Office removes the block before the expiration of the period, the Head of the Office removes the block before the expiration of the period, or there is a court order in the form of a decision or determination.

Blocked records by law enforcers are deleted if the criminal case currently under investigation and prosecution has been terminated; or investigators request the deletion of blocked records. The request for deletion of block records is submitted directly in writing to the Head of the Land Office ${ }^{14}$.

Blocking removal is carried out by the Head of the Land Office or an official appointed in the relevant Land Book and Measurement Letter. The removal of

13 Ong Argo Victoria, (2018) Waqf Al-Nuqūd In Indonesia (In Law Perspective), Jurnal Pembaharuan Hukum Vol 5, No 1 Universitas Sultan Agung, http://jurnal.unissula.ac.id/index.php/PH/article/view/2999

${ }^{14}$ Deen, Thaufiq., Ong Argo Victoria \& Sumain. (2018). Public Notary Services In Malaysia. JURNAL AKTA: Vol. 5, No. 4, 1017-1026. Retrieved from http://jurnal.unissula.ac.id/index.php/akta/article/view/4135 
the block shall at least contain a description of the time (hours, minutes and seconds) and the date of recording, the subject who submitted the application, the reason for the deletion.

Provisions for recording blocks in the land book and measuring documents and their ratification mutatis mutandis (with necessary or important changes) with provisions for removing blocks the deletion of the block record shall be notified in writing by means of an official letter to the block applicant and/or the party concerned appropriately ${ }^{15}$.

Legal protection for buyers who have good intentions in the event of confiscation or blocking of land rights certificates. A buyer who has good intentions in making a sale and purchase of anything, if he has fulfilled the material requirements and formal requirements at the time of making the transfer of the sale and purchase of land, against the legal act of buying and selling, he always gets legal protection because he is considered to have fulfilled the conditions of sale and purchase, because have gone through a legal Sale and Purchase procedure.

\subsection{Obstacles and Settlement of Land Rights Holders in the Case of Implementing Block Recording at the Banjarnegara Regency Land Office}

Land Registration in Indonesia is carried out based on Government Regulation Number 10 of 1961 concerning Land Registration which was later replaced by Government Regulation Number 24 of 1997 concerning Land Registration which is a refinement of the scope of Land Registration activities based on Article 19 paragraph (2) of Act No. 5 of 1960 concerning Basic Agrarian Regulations (UUPA) which include: measurement, mapping and bookkeeping of land, registration and transfer of land rights as well as providing proof of rights as a strong evidence. Land registration activities are carried out by the National Land Agency (BPN), where the implementation is carried out by the Head of the Land Office (Land Office). ${ }^{16}$

Based on Presidential Regulation Number 20 of 2015, the National Land Agency (BPN) is a Non-Ministerial Government Institution which is under and responsible to the President and led by the Head of the National Land Agency which has the task of carrying out government duties in the land sector in accordance with the provisions of laws and regulations.

\footnotetext{
${ }^{15}$ Sukarmi, S., \& Victoria, A. (2018). Cash Waqf in Sustaining Of Indonesian Society "In Legal \&amp; Economic Perspective". AL-ITQAN: JOURNAL OF ISLAMIC SCIENCES AND COMPARATIVE STUDIES, 2(1), 83-97. https://doi.org/10.31436/al-itqan.v2i1.43

${ }^{16}$ Ghazali, Kurniawan, 2013, Cara Mudah Mengurus Sertifikat Tanah, Jakarta: Kata Pena, p. 65
} 
The Banjarnegara Regency Land Office is a working unit of the National Land Agency in the province. The task of the City Land Office is to carry out Land Rights Registration and maintain a general register of Land Registrations, one of which is to block certificates at the request of interested parties. ${ }^{17}$

The implementation of certificate blocking is one of the duties and functions of the Head of the Land Rights and Land Registration Section whose process is carried out by the Rights Registration Sub-Section. The duties and functions of the Rights Registration Sub-Section are to prepare the implementation of Land Rights Registration, recognition and confirmation of the conversion of other rights, property rights to flat units, land management rights, waqf land, other juridical data, physical data of land parcels, computerized data land services and maintain a register of land books, a list of names, a list of land rights and certificates as well as other registers in the field of land registration. ${ }^{18}$

Certificate blocking is carried out by an applicant by submitting an application which is submitted at the Service counter, after which the application document is submitted to Counter II to be examined for its physical completeness. If the documents submitted are complete, the counter officer will provide a Document Receipt (STTD) and make a Deposit Order (SPS) for the Applicant. If the document is incomplete, it will be returned to the applicant. After receiving the STTD and SPS, the applicant makes a payment at Counter III and for further inspection and registration of blocking is carried out by the Implementing Officer of the Rights Registration Sub-Section. After recording the blocking, the document is submitted to the applicant through Counter IV. ${ }^{19}$

The provisions regulated in Article 126 PMA/KBPN 3 of 1997 concerning Implementing Regulations of PP 24 of 1997 which states that interested parties can request to be recorded in the land book that land rights or Property Rights on Flat Units will be the object of a lawsuit in the Court by submitting a copy of the suit in question. The record is automatically deleted within 30 days from the date of recording or if the party requesting the recording has withdrawn the request before the time has expired. If the time expires without any follow-up, and in the future the same applicant wishes to apply again for the same reason, the Land Office will reject the application.

In general, the factors causing the blocking of land rights certificates at the Banjarnegara Regency Land Office are because land rights are disputed and

\footnotetext{
${ }^{17}$ Interview with Dijah Mohammad Hidajat, as Head of the Land Rights Registration Subsection of the Banjarnegara Regency Land Office, on February 09, 2021

18 Ibid.

19 Ibid.
} 
confiscated by the Court or disputes outside the court, Land Rights are confiscated by PUPN/KPKNL in connection with the settlement of state receivables, so the parties are requested to the Head of the Land Office for blocking. The legal consequences for the owner of the certificate for blocking the Certificate of Land Rights at the Land Office are that the land is temporarily unable to take legal action and also the Land Office has the authority to refuse the registration of the Transfer and Transfer of Names to the Land Rights. So the transfer of rights and registration (name transfer) can only be done after the block is lifted.

The obstacle to the Land Office in blocking land certificates is the absence of the authority to examine and examine material juridical data on the blocking application submitted by the parties. If the party whose name is listed as the owner of the blocked land rights object to the blocking, then the objection must go through a lawsuit to the Court.

\section{Closing}

1) It has become a standard operating procedure from the Land Deed Official that for every object to be transferred to or pledged, the certificate of title of the object must be checked with the Land Office before signing the deed. Provisions regarding checking are in accordance with Article 34 PP Number 24 of 1997 concerning Land Registration which stipulates that certificate checking is an activity carried out to find out physical data and juridical data stored in registration maps, land registers, measuring letters, and land books. 2) Legal protection for holders of land rights certificates in the event of a certificate blocking by the Banjarnegara Regency Land Office, namely it is not allowed to apply for a block of land rights that have been certified, as a form of legal certainty by the state for legal certificates and legal protection by the state for land title certificates proof of registration issued by the Land Office itself. Blocking removal is carried out by the Head of the Land Office or an official appointed in the relevant Land Book and Measurement Letter. The removal of the block shall at least contain a description of the time (hours, minutes and seconds) and the date of recording, the subject who submitted the application, the reason for the deletion. 3) Provisions for recording blocks in the land book and measuring documents and their ratification mutatis mutandis (with necessary or important changes) with provisions for removing blocks the deletion of the block record shall be notified in writing by means of an official letter to the block applicant and/or the party concerned appropriately. 4) Obstacles and settlement of Land Rights Holders in the event of the implementation of block registration at the Banjarnegara Regency Land Office, namely the holders of land rights in the case of the implementation of the 
blocking registration occurs due to ignorance of the people who will carry out the sale and purchase transaction that the certificate held or owned by the owner is not necessarily the same as Land Book in the Land Office.

\section{References}

Journals:

[1] Chintya, Agnisya Putri, Farris Nur Sanjaya, Gunarto. (2018). "Efektivitas Pengecekan Sertifikat Terhadap Pencegahan Sengketa Tanah Dalam Proses Peralihan Hak Atas Tanah". Jurnal Akta, Vol. 5 No. 1.

[2] Huurin In, Naila, (2019). "Implementasi Blokir Sertipikat Kepemilikan Hak Atas Tanah Di Kantor Bpn Kota Surabaya". Simposium Hukum Indonesia, Volume 1 No. 1.

[3] Isnaini, Moch., (2000). Benda Terdaftar Dalam Konstelasi Hukum Indonesia, Jurnal Hukum, Nomor 13 Volume 7, 7 April

[4] Sihaloho, R. (2019). "Pelaksanaan Blokir Sertipikat Hak Atas Tanah Ditinjau Dari Aspek Kepastian Hukum", Notarius, Vol. 12 No. 2.

[5] Ong Argo Victoria, (2018) Waqf Al-Nuqūd In Indonesia (In Law Perspective), Jurnal Pembaharuan Hukum Vol 5, No 1 Universitas Sultan Agung, http://jurnal.unissula.ac.id/index.php/PH/article/view/2999

[6] Deen, Thaufiq., Ong Argo Victoria \& Sumain. (2018). Public Notary Services In Malaysia. JURNAL AKTA: Vol. 5, No. 4, 1017-1026. Retrieved from http://jurnal.unissula.ac.id/index.php/akta/article/view/4135

[7] Sukarmi, S., \& Victoria, A. (2018). Cash Waqf in Sustaining Of Indonesian Society "In Legal \&amp; Economic Perspective". AL-ITQAN: JOURNAL OF ISLAMIC SCIENCES AND COMPARATIVE STUDIES, 2(1), 83-97. https://doi.org/10.31436/al-itqan.v2i1.43

Books:

[1] Cholid dan Achmadi, Abu, 2007, Metodologi Penelitian, PT. Bumi Aksara, Jakarta

[2] Ghazali, Kurniawan, 2013, Cara Mudah Mengurus Sertifikat Tanah, Kata Pena, Jakarta.

[3] Hafidhuddin, Didin, 2006, Agar Layar Tetap Terkembang: Upaya Menyelamatkan Umat, Gema Insani Press, Jakarta

[4] Harahap, M., 2007, Hukum Acara Perdata. Sinar Grafika, Jakarta.

[5] Harsono, Boedi, 2008, Hukum Agraria indonesia, Sejarah Pembentukan Undang-Undang Pokok Agraria Isi dan Pelaksanaannya, jilid 1, Hukum Tanah Nasional, Cetakan ke Duabelas, Djambatan, Jakarta

[6] Hidayat, Nuim., Quthb, Sayyid, 2005, Biografi dan Kejernihan Pemikirannya, Gema Insani Press, Jakarta

[7] Joko Subagyo. J, 2006, Metode penelitian Dalam Teoridan Praktek, Cetakan Kelima, Rineka Cipta, Jakarta 
[8] Jujun, S.Suriasumantri, 2007, Filsafat IImu Sebuah Pengantar Populer, Pusataka Sinar Harapan, Jakarta

[9] Lubis, Yamin dan Lubis, Rahim, 2010, Hukum Pendaftaran Tanah, Mandar Maju, Bandung

[10] M. Hadjon, Philipus, 1987, Perlindungan Rakyat Bagi Rakyat di Indonesia (sebuah Studi tentang Prinsip-Prinsipnya, Penanganannya oleh Pengadilan dalam Lingkungan Peradilan Umum dan Pembentukan Peradilan Administrasi Negara), PT. Bina Ilmu, Surabaya

[11] Mahmud Marzuki, Peter, 2010, Penelitian Hukum, Kencana Prenada Media Group, Jakarta

[12] Muchsin, 2003, Perlindungan dan Kepastian Hukum Bagi Investor Dilndonesia, Magister Ilmu Hukum Program Pascasarjana Universitas Sebelas Maret, Surakarta.

[13] Parlindungan. AP, 1988, Pendaftaran Tanah Tanah dan Konfersi hak milik atas tanah menurut UUPA, Alumni, Bandung

[14] Pusat Bahasa Departemen Pendidikan Nasional, 2002, Kamus Besar Bahasa Indonesia, Balai Pustaka, Jakarta

[15] Rahardjo, Satjipto, 1983, Permasalahan Hukum di Indonesia, Alumni, Bandung.

[16] Rahardjo, Satjipto, 2000, Ilmu Hukum, Citra Aditya Bakti, Bandung [17] Rasjidi, Lili dan Arief Sidharta, B., 1994, Filsafat Hukum Madzab dan Refleksi, PT. Remaja Rosda Karya, Bandung

[18] Remy Sjahdeini, Sutan, 2009, Kebebasan Berkontrak dan Perlindungan Yang Seimbang Bagi Para Pihak Dalam Perjanjian Kredit Bank di Indonesia,: PT. Pustaka Utama Graffiti, Jakarta

[19] S.W. Sumardjono, Maria, 2005, Kebijakan Pertanahan Antara Regulasi dan Implementasi, Buku Kompas, Jakarta.

[20] Setiono, 2004. Rule of Law (Supremasi Hukum), Magister Ilmu Hukum Program Pascasarjana Universitas Sebelas Maret, Surakarta

[21] Sianturi, P. T., 2013, Perlindungan Hukum Terhadap Pembeli Barang Jaminan Tidak Bergerak Melalui Lelang. Mandar Maju, Bandung.

[22] Soekanto, Soerjono, 2006, Pengantar Penelitian Hukum, Cetakan ke-3, UI Press, Jakarta

[23] Soekanto, Soerjono dan Mamudji, Sri, 1985, Penelitian Hukum Normatif, Rajawali Press, Jakarta

[24] Soekanto, Soerjono, 1984, Pengantar Penelitian Hukum, Ui Press, Jakarta.

[25] Soekanto, Soerjono, 1986, Pengantar Penelitian Hukum, UI Press, Jakarta.

[26] Soetrisno, Loekman, 1995, Menuju Masyarakat Partisipatif, Penerbit Kanisius, Yogyakarta.

[27] Sumardjono, Maria, didalam Silviana, Ana, 2012, Teori Dan 
Praktek Pendaftaran Tanah, Badan Penerbit Universitas Diponegoro, Semarang

[28] Supriadi, 2008, Hukum Agraria, Penerbit Sinar Grafika, Jakarta.

[29] Waluyo, Bambang, 1991, Penelitian Hukum Dalam Praktek, Sinar Grafika, Jakarta

[30] Yulian Isnur, Eko, Tata Cara Mengurus Surat-surat Rumah dan Tanah, Pustaka Yustisia, Yogyakarta.

Regulations:

[1] Act No. 5 of 1960 concerning Basic Agrarian Regulations (UUPA)

[2] Government Regulation Number 24 of 1997 concerning Land Registration

[3] Government Regulation Number 24 of 2016 concerning Land Deed Maker Officials (PPAT)

[4] Regulation of the Minister of Agrarian Affairs and Spatial Planning/Head of the National Land Agency of the Republic of Indonesia Number 13 of 2017 concerning Procedures for Blocking and Confiscation

Internet:

[1] Aristoteles, didalam Teori atau Konsep Keadilan Menurut Aristoteles, http://www.siswamaster.com/2016/01/teori-keadilan-menurut-aristotelesdan-contoh.html, accessed on 26 January 2021

[2] http://www.hukumonline.com/klinik/detail/It5a6e858b613b3/perbedaan -pemblokiran-tanah-dengan-penyitaan-tanah, accessed on 26 January 2021

[3] http://raypratama.blogspot.co.id/2015/04/teori-perlindunganhukum.html.

[4] http://tesishukum.com/pengertian-perlindungan-hukum-menurut-paraahli/

[5] Muhammad Gufron, Tata Cara Blokir dan Sita, https://www.hukumproperti.com/pertanahan/tata-cara-blokir-dan- sita/, accessed on 26 January 2021

[6] No name, Tujuan Hukum Menurut Gustav Radbruch, https://bolmerhutasoit. wordpress.com/2011/10/07/artikel-politikhukum-tujuan-hukum-menurut-gustav-radbruch/

[7] Sakhiyatu Sova, Tiga Nilai Dasar Hukum Menurut Gustav Radbruch, http://www.scribd.com/doc/170579596/Tiga-Nilai-Dasar-Hukum-

Menurut-Gustav-Radbruch\#scribd 